\title{
Mariusz Rybak*
}

\section{POWIEDZ MI, CO JESZ, A POWIEM CI, KIM JESTEŚ}

Montanari, Massimo. 2010. Il cibo come cultura [Jedzenie jako kultura], wydanie czwarte, Roma-Bari: Editori Laterza.

Do niedawna jedzenie jako obiekt badań nie znajdowało szerszego zainteresowania w naukach społecznych. Było elementem codzienności nazbyt prozaicznym i nazbyt oczywistym. Co prawda problematyka żywności pojawiała się często w dziełach klasyków antropologii, takich jak Bronisław Malinowski czy Claude Lévi-Strauss, ale odgrywała tam rolę raczej marginalną, istotne były przede wszystkim związane z jedzeniem rytuały.

Niewielka waga, jaką przywiązywały tradycyjnie do jedzenia narody zamieszkujące na północ od Alp i wschód od Francji, zdaje się przekładać na ich zainteresowanie żywnością także na polu nauki. Tematyka zajmuje zatem przede wszystkim naukowców włoskich (np. Alberto Capatti, Silvano Serventi) czy francuskich (np. Jean-Louis Flandrin, François Sabban, Julia Csergo), którzy koncentrują się jednak na bogatych tradycjach swoich krajów - nasza część Europy pozostaje swoistą terra incognita.

O jedzeniu w odniesieniu do kultury wspomina się w Polsce trochę w ramach socjologii żywienia, trochę $\mathrm{w}$ ramach kulturoznawstwa i antropologii, ale poważnych publikacji poświęconych wyłącznie tej tematyce trzeba szukać raczej z lupa, a z tych ewentualnie odnalezionych znaczna większość to tłumaczenia. Czy nadal pokutują nawyki lekceważenia kultury kulinarnej, spowodowane skromną ofertą handlową w czasach komunizmu, kiedy to z polskich kuchni zniknęły liczne przyprawy i zioła, a jakość wina w krajach o tak długich tradycjach winiarskich jak Węgry, Rumunia czy Czechy obniżyła się do tego stopnia, że wyroby tych państw dopiero obecnie wracają powoli do dawnej świetności.

Ostatnie dwadzieścia lat przyniosły zmiany także na tym polu. Polacy zwracają się ku przedwojennym tradycjom oraz zagranicznej ofercie kulinarnej. W tym, co i jak jedza, zaczynają manifestować swoje postawy, status, tożsamość, aspiracje. Jacek Kurczewski w jednym z udzielonych wywiadów powiedział, że „tutaj w Polsce, acz nie tylko, widać, że rynek gastronomiczny się rozwija i coraz więcej ludzi będzie chodziło do restauracji i coraz więcej będzie interesowało się gotowaniem i znajdowało pracę czy zakładało biznes

\footnotetext{
* Humboldt-Universität zu Berlin, mariusz.rybak@hu-berlin.de
} 
w sferze gastronomicznej. Ważna jest umiejętność połączenia wiedzy socjologicznej i psychologiczno-kulturowej z kuchnią (...) Istnieje coraz silniejsza tendencja, by nadać jedzeniu, które jest nieodzowne, także rangę przyjemności i sztuki, a sztuka wymaga wiedzy" (Łopanowski 2009, 26-27). Wiedza na ten temat stanowi jednak w Polsce lukę, którą kolejne pokolenia socjologów, antropologów, historyków czy kulturoznawców mogą (i chciałoby się dodać: i powinny) wypełnić. Dla tych, którzy szukają wprowadzenia w tematykę, szybkiego przeglądu możliwie najszerszego spektrum tematów dotyczących jedzenia $\mathrm{z}$ perspektywy kulturowej i historycznej, książka Massima Montanariego wydaje się być propozycją właściwą.

Recenzję brazylijskiego wydania książki (editora SENAC, São Paulo 2008) Maria de Fátima Farias de Lima rozpoczęła od słów: „Lekka, ciekawa i absolutnie intrygująca (...)” (2009). Opinii tej nie zaprzeczę, poczuwam się jednak do obowiązku wyjaśnienia polskiemu czytelnikowi, dlaczego dobrano takie, a nie inne przymiotniki. W ciagu ostatnich trzydziestu lat Montanari opublikował trzydzieści książek dotyczących przede wszystkim historii średniowiecza oraz historii jedzenia, zwłaszcza w odniesieniu do kwestii tożsamości, władzy czy wykształcania się struktur społecznych. Il cibo come cultura należy do tych jego publikacji, które skierowane są do możliwie szerokiego grona czytelników, nie tylko studentów i naukowców. Tym samym autor zdecydował się na język żywy, zrozumiały także dla niewtajemniczonych.

Ciekawa jest każda strona wzbogacająca czytelnika o nowe informacje dotyczące fenomenu, który wydaje się tak znany i bliski. Informacje te bardzo często nie odpowiadają naszym wyobrażeniom i teoriom znanym z mediów, literatury na temat cudownych diet czy przewodników turystycznych. Dowiadujemy się m.in., że zarówno mądrość przodków, dieta śródziemnomorska, jak i „,wielowiekowa” kuchnia regionalna oparta tylko na produktach lokalnych są konceptami stosunkowo nowymi i mają niewiele wspólnego z odwiecznymi tradycjami. Region Morza Śródziemnego podlegający wpływom wielu kultur, chociażby ze względu na swoją rolę w handlu pomiędzy Europą, Afryką i Azją, a potem także obiema Amerykami, rozwijał nieprzerwanie swoją kuchnię na podstawie coraz to nowych produktów. Montanari pisze, że ze starożytnej diety regionu przetrwały do dziś wino, oliwa, chleb i cebula. Produkty kojarzone z regionem - bazylia, pomidor, pasta czy bakłażany - pojawiły się znacznie później. Także idea kuchni regionalnej czy lokalnej jest przede wszystkim produktem dziewiętnastowiecznych procesów tożsamościotwórczych, towarzyszącym rozwojowi nacjonalizmów. Kuchnie średniowiecza i renesansu sięgały chętnie do wszystkich dostępnych produktów - im większa różnorodność, tym większy prestiż, jako że składniki egzotyczne świadczyły o bogactwie. Lokalna była z konieczności tylko kuchnia chłopska, ale i ona niewiele miała wspólnego z tą, która dziś nosi to samo miano.

Intrygujące jest natomiast, że autor w owym procesie odczarowywania świata kuchni nie pozwala czytelnikowi stracić nią zainteresowania. Urokliwe stereotypy ustępują miejsca fascynującym faktom historycznym. Świat jedzenia nie traci na swej złożoności i fantazji, mimo że opuszcza strefę romantycznych tekstów z reklam i przewodników na rzecz nauki. Książka zachęca tyleż do refleksji naukowej, ile oddania się jako konsument pasji odkrywania tej bliskiej a dalekiej rzeczywistości.

Autor tego „lekkiego, ciekawego i absolutnie intrygującego” dzieła, Massimo Montanari, jest profesorem historii średniowiecza na Uniwersytecie Bolońskim. W swoich badaniach 
podejmuje on jednak problemy z pogranicza socjologii, antropologii i historii. Jego książki doczekały się licznych tłumaczeń, na polskie pozostaje nam czekać. Celem tej recenzji jest także zaproszenie polskiej akademii do zgłębienia tematyki poruszonej w publikacji Montanariego, a tym samym sprowokowania tłumaczeń.

Montanari postuluje już w tytule swojej książki, że jedzenie jest elementem kultury. Smak jest jego zdaniem konstruowany społecznie. Wyrabianie smaku u dzieci jest częścią wychowania, akulturacji w danej społeczności. Nie tylko maniery przy stole, ale także to, co dobre i niedobre, jadalne i niejadalne, zdrowe i niezdrowe muszą zostać przyswojone w procesie socjalizacji. Ponadto to, co znajdziemy na stole danego społeczeństwa, w danych czasach, wyjaśnia nie tylko smak i stopień dobrobytu, lecz pozwala także na analizę stosunków władzy, własności i pracy.

Książka składa się z czterech większych bloków tematycznych, a te z kilku krótszych rozdziałów. Pierwszy blok zatytułowany jest Konstruowanie własnej żywności (Construire il proprio cibo) i koncentruje się na przeciwstawności natury i kultury, opisując rolę niektórych gatunków roślin w rozwoju cywilizacji (tzw. piante di civiltà, tj. rośliny cywilizacji czy też cywilizujące). Wokół takich gatunków organizuje się całe życie społeczne, od stosunków natury ekonomicznej i form władzy aż do kultury i religii. Jedzenie osiadłych, rolniczych społeczności (chleb, wino, piwo, oliwa, ser itd.) zostaje określone mianem konstrukcji kulturowej, ponieważ nie istnieje jako takie w naturze, a poprzez to zyskuje wymiar symboliczny - odróżnia człowieka od świata zwierząt. W tej samej części autor omawia również aspekt czasowy i przestrzenny żywności, jej sezonowość, przechowywanie, konserwowanie, czy pochodzenie, bardzo ostrożnie jednak rozróżniając produkty regionalne i importowane.

Drugi blok tematyczny, Wynalazek kuchni (L'invenzione della cucina), poświęcony jest kwestiom, takim jak: społeczna definicja tego, co jadalne i niejadalne, gusta i preferencje, post, znaczenie odmiennych form przygotowywania posiłku (gotowanie, pieczenie itd.), różnice pomiędzy kuchnią elit i prostego ludu, w końcu jedzenie z perspektywy „medycznej”, a więc historyczny rozwój idei posiłków ,zdrowych” i ,niezdrowych”. To tutaj zdemaskowany zostaje fakt, że indywidualny wybór diety oparty jest nie tylko na argumentach ekonomicznych i zdrowotnych, ale także symbolicznych. Znaczenia kulturowe, których jesteśmy „,nosicielami i w pewien sposób więźniami”’1 (Montanari 2010: 59), zostają przypisane określonym produktom czy sposobom przyrządzania. Tym samym odżywianie wkracza na teren tożsamości. Jednym z przykładów jest amerykański kult barbecue, za którym stoi wyobrażenie życia łowcy czy może kowboja. Istotnie polowanie stanowi część American way of life, cenionego stylu życia, kojarzonego przez samych Amerykanów z wolnością i niezależnością, a także brakiem przywilejów klasowych (historyczny przywilej polowania wśród brytyjskiej arystokracji).

Montanari tytułuje trzecią część swojej książki Przyjemność (i obowiazek) wyboru (Il piacere (e il dovere) della scelta), kierując tym razem swoją uwagę na gusta. Tematy tu poruszone są dla socjologów i antropologów prawdopodobnie najciekawsze w całej publikacji. Zaprezentowana zostaje „struktura smaku”. Autor zaczyna pierwszy rozdział od słów: „Jedzenie nie jest 'dobre' albo 'złe' w sposób absolutny: ktoś nauczył nas rozpoznawać je jako takie. Organem smaku nie jest język, lecz mózg, organ zdeterminowany kulturowo (a przez

\footnotetext{
1 Wszystkie thumaczenia pochodzą od autora recenzji.
} 
to też historycznie), poprzez który zostają wpojone i przekazane kryteria oceny" (Montanari 2010: 73). Smak jest zatem fenomenem społecznym, uwarunkowanym kulturowo i przekazywanym w procesie socjalizacji. Kryteria „dobre” i „złe”, czy też ,jadalne” i „niejadalne”, rzadko mają charakter obiektywny. Nie spożywamy wielu produktów, które w gruncie rzeczy są jadalne, a nawet zdrowe. Na wstępie swojej książki Jedzenie zwierząt Jonathan Safran Foer pisze, że Amerykanie konsumują mniej niż 0,25 procent znanych na świecie produktów żywnościowych. W Polsce nie jemy np. psów, koni czy wodorostów, co nie znaczy jednak, że mamy do czynienia z pokarmami szkodliwymi czy trującymi. Montanari kontynuuje swoją myśl następująco: „(...) smak nie jest wcale rzeczywistością obiektywną i nieprzekazywalną, lecz właśnie kolektywną i przekazywalną. Jest doświadczeniem kulturowym, przekazywanym od momentu narodzin, wraz z innymi zmiennymi, które uczestniczą w definiowaniu 'wartości' danego społeczeństwa" (Montanari 2010: 74). O historii, jakości i stanie polskiego smaku niewiele nadal wiadomo i wiele jest tu do zrobienia. Jak odżywia się Polak z małego miasta, robotnik, o niskim dochodzie? A co je młoda, ambitna Polka, wykształcona, podróżująca, świetnie zarabiająca, w jednym z wielkich miast? Jakie wartości łączą Polacy z konkretnymi produktami czy ich grupami, z dietami i kuchniami, zwyczajami żywieniowymi? Jaka jest zależność między dietą a tożsamością - narodową, regionalną, lokalną? Co pozostało z naszej historii, a co się zmienia? Zmiany są przecież niezwykle widoczne: wyobrażenie wielu obcokrajowców o wódce jako narodowym trunku Polaków już dawno straciło potwierdzenie w rzeczywistości; mocne trunki wyprzedziło najpierw piwo, a niedawno także wino. Jeśli przyjrzeć się udziałowi trzech kategorii - wyroby spirytusowe, piwo i wino - w ogólnej konsumpcji alkoholu, to Polacy piją procentowo mniej wódki i podobnych produktów niż Niemcy, za to więcej wina niż ci ostatni (World Health Organization 2011). Są to istotne tendencje w społeczeństwie, za którymi znajdziemy skomplikowaną mieszankę wartości, norm, wyobrażeń i symboli.

Ostatnia część zatytułowana jest Jedzenie, mowa, tożsamość (Cibo, linguaggio, identità) i kontynuuje problem tożsamości zbiorowej, ujawniającej się w zwyczajach żywieniowych. Jedzenie zostaje porównane do języka, z jego gramatyką, słownictwem i metaforami. „Tak jak język mówiony, system odżywiania wyraża i przekazuje kulturę tego, kto ją praktykuje, jest depozytariuszem tradycji i zbiorowej tożsamości” (Montanari 2010: 153). W ten sposób możemy mówić o odżywianiu jako instrumencie autoprezentacji oraz wymiany kulturowej. To, kim jestem albo jak chciałbym być postrzegany, mogę sugerować przez takie wybory jak wegetarianizm, abstynencja, koszerność, halal, regularne zamawianie w restauracji sałatki albo też wielkiego steku. Nils-Arvid Bringéus pisał, że zwyczaje żywieniowe są nacechowane znaczeniami o charakterze ideologicznym. W istocie to, co jem, może wskazywać na moją religię, poglądy polityczne, kulturę pochodzenia, status społeczny i ekonomiczny.

Tekst pełen jest przykładów, anegdot, nazwisk i miejsc. Choć znaczna część tych informacji odnosi się to Włoch i często do regionu Emilia-Romagna (popularnego wśród Polaków z uwagi na Rimini i dobrą kuchnię), to autor sięga również po przykłady z innych krajów. Koncepcja jedzenia jako elementu kultury ma charakter uniwersalny i nie ogranicza się do rejonu śródziemnomorskiego, kojarzonego ze szczególną dbałością o ten aspekt codziennego życia.

Montanari pisze już na wstępie, że swoimi przemyśleniami nie uda mu się być może poważnie wzbogacić teoretycznego dyskursu na temat fenomenu kultury i tożsamości. Ma 
natomiast zamiar zaproponować interdyscyplinarne spojrzenie na jedzenie jako zjawisko kulturowe, spojrzenie nie tylko historyczne, ale też socjologiczne i antropologiczne. Czy mu się udało? Wydaje się, że poruszając tak wiele tematów oraz otwierając się na szersze grono czytelników, nie zapomniał o pobudzaniu naukowej ciekawości. Ostatnie dziesięciolecia są nacechowane w świecie akademii konceptami interdyscyplinarności i niszowości zarazem. Raz łączymy różne dziedziny nauki, to znów rozbijamy je na atomy, by stworzyć coś wyspecjalizowanego. Montanari proponuje kolejny taki eksperyment, w którym spotykają się socjologia żywności, antropologia kulturowa i historia, a który wzbogacić można na pewno o ekonomię kultury, filozofię czy kulturoznawstwo.

\section{BIBLIOGRAFIA}

Farias, Lima de, Maria de Fátima. 2009. Resenha: Comida como cultura, „Revista de Ciências Sociais", no. 40(1), s. 107-111.

Łapanowski, Grzegorz. 2009. Socjologia prosto z garnka (rozmowa z Jackiem Kurczewskim), w: Tomasz Kukołowicz (red.), Po co nam socjologia? Ksiażka dla kandydatów na studia socjologiczne i studentów, Warszawa: Fundacja na rzecz Warsztatów Analiz Socjologicznych, s. 22-27; zob. również: www.is.uw.ed.pl/wp-content/uploads/03_Kurczewski.pdf. Montanari, Massimo. 2010 (2004). Il cibo come cultura, Roma-Bari: Editori Laterza.

Nils-Arvid, Bringéus. 2011. Man, Food and Milieu: a Swedish Approach to Food Ethnology, East Lothian: Tuckwell Press.

Safran, Foer, Jonathan. 2012. Tiere essen, Frankfurt am Main: Fischer Taschenbuch Verlag. World Health Organization. 2011. Global status report on alcohol and health, Geneva: WHO Press. 